\title{
Language for students without interest in languages: challenges of foreign language grammar
}

\author{
Nataliya M. Belenkova - Irina I. Kruse - Victoria V. Davtyan - Doris Wydra
}

DOI: 10.18355/XL.2018.11.01.23

\begin{abstract}
The importance of the paper is provided by the fact that multilingualism being one of the most important characteristics of the contemporary society envisages the study of two and more foreign languages at non-language higher education institutions. The present research aims to examine and reveal grammatical difficulties the students face while learning English as the first foreign language and Spanish and German as the second ones. The difficulties learners experience are mostly connected with interlanguage interference, in particular, Russian students' grammar interference. The methods used to achieve the goal focus on the analytical review of the contemporary research of the issue under study, the survey of the participants of the teaching experiment, and the method of mathematical statistics. The paper presents the findings of the experiment held by the Department of Foreign Languages at Law Institute of RUDN University (Peoples' Friendship University of Russia). The findings of the research can be used in teaching foreign languages for specific purposes in higher education institutions and as a ground for further development of the issue.
\end{abstract}

Key words: programmed learning technologies, information and communication means, development of lexical skills

\section{Introduction}

Research in linguistics have an applied character; it is always carried out for the general or professional use of the foreign language. Theoretical issues of linguistic studies are implemented in practical realizations. That is why linguistics and the methodology of teaching foreign languages are interrelated disciplines especially when the issues of higher education are touched.

Foreign languages were the mandatory part of non-language higher education institutions curricula for years. However, the attitude to the foreign language differed greatly as the international environment changed and the demands to professional awareness of the university graduates in the foreign languages depended mostly on the social and political climate in the world.

In the XX century, the main accent in a new state (Russia/the Soviet Union) was made on the reception of the texts in the foreign languages and their translation, i.e., the grammar rules, syntax structure of sentences and terminology of a particular setting was of primary importance. As the citizens of the country could not afford traveling abroad, the development of verbal communication was not crucial (Garrard, 1962).

The German Language was widely spread at that time. Historical events of the $40 \mathrm{~s}$ caused much concern about teaching foreign languages.

After 1945, the interest in the German language faded, and English took the first place among the languages studied at the higher education institutions. However, the unfavorable international situation restricted the curricula of the foreign languages to the perception of the written information in a foreign language.

Consequently, the studies in linguistics were concentrated on the passive vocabulary, terminology of a particular setting and grammar structures typical of the written form of English.

Changes occurred in the world in the 90s of the last century gave impetus to the study of the foreign language productive forms. These changes helped the graduates of the higher education institutions realized the necessity to speak and write in a foreign 
language. Multilingualism as a world tendency enhanced the role of English as the language of international communication and at the same time caused a new wave of interest to the other European languages, mainly to German, French, and Spanish.

Realizing the importance of the awareness of two or more foreign languages some Russian Universities (e.g., Law Faculty of RUDN University) started a new course aimed at developing the students' foreign language skills in English and other European Languages and regarding the legal environment of the European Union (Atabekova, 2011).

The study of two and more foreign languages causes the interference of the native and foreign languages, on the one hand, and between the foreign languages, on the other hand.

The new reality of the international environment, the historical background and the present state of the issue determined the hypothesis of the current research: the new role of foreign languages in non-language special setting determine the importance of the up-to-date analysis of the grammar issues and their practical implementation in non-language higher education.

The subject matter of the research is the analysis of the students' review of the grammar phenomena that cause extreme difficulties in studying a foreign language for specific purposes.

This paper aims to generalize the grammar phenomena causing more difficulties for the students and put forward the ways to cope with the linguistic challenges mentioned above.

The tasks of the current research are:

- to review the literature related to the topic of the paper;

- to examine the findings of the survey held by the teachers and students of the non-language university, to generalize the data of the survey;

- to work out the recommendations aimed at overcoming the linguistic challenges the students of non-language higher education institution face when studying foreign languages for specific purposes.

\section{Literature Review}

To determine the linguistic issues that cause many difficulties in language training of the students in non-language higher education institutions, one should study what aspects of interlinguistic interference are most complicated for non-language speakers to understand and deal with in practical activity.

This topic is widely debated in research papers and books.

The major part of the difficulties are connected with the grammar of the second language and its syntactic structures: passive constructions and progressive forms in English (Yalçın, Spada 2016); constructing interrogative sentences (Famularsih, 2014); the correct perception of -ed forms (Ellis et al., 2006); dative clitics in clitic doubling structures in Spanish (Escobar-Álvarez, 2017); the issues of grammatical gender in French (Ayoun, 2017).

The academic literature reveals the linguistic challenges related to specific settings. Malcolm Coulthard and Alison Johnson focus on the issues that cause much misunderstanding in the legal setting. Analyzing the legal practice of non-language university graduates they noted that the most difficult linguistic aspects for understanding are as follows: bunches of compound nouns, nominalization of verbs, a complex structure of clauses inside one sentence; passive constructions, several negatives in a single phrase (Coulthard, Johnson, 2007). The specific features of legal texts (commercial and finance law) in German are also highlighted (Košárková, 2013). 
The level of interlanguage interference can also depend on the native language of the students (Agcam et al., 2015; Hopkinson, 2007; Oller, 1979; Bondarenko, 2014).

In the opinion of the contemporary researchers the linguistic interference and students' misunderstanding occur not only due to the language complexity but also because of the students' psychological individual features such as their level of cognition (Housen, Simoens, 2016); individual differences of their development including the capacity for language learning, memory etc. (Villegas et al., 2017).

The findings of the current research in linguistics and interlanguage interference are taken into consideration in the recent publications. R. Huddleston and G.K. Pullum (2002) focus on a more descriptive way of presenting English grammar. This way differs from the traditional way and is supported by a great number of practical examples. New developments in grammar study are revealed by G. Yule (2016).

The literature review showed that the problem of interlanguage interference is viewed from different angles. However, the contemporary research does not demonstrate the Russian students' grammar interference in such pairs of foreign languages as English - Spanish or English - German in a legal setting. The lack of any data on this issue makes this research topical.

\section{Materials and Methods}

The comparative analysis of various issues connected with the topic was used as the main research method. First, the samples of the students' English - Russian translations of the legal setting texts were compared. The texts were the examples of legal cases (https://www.unodc.org/cld/v3/htms/cldb/index.html?lng=en), legal documents, extracts from police interviews and court proceedings (Coulthard \& Johnson, 2007).

Then the students' translations of the legal texts from their second foreign languages into Russian should be examined. Primary, the equal number of students studying German, French, and Spanish was to participate in the experiment. However, during the experiment, there were fewer learners of French as a second foreign language and to get accurate statistical data this category of the learners was excluded from the output of the experiment. Only the students learning German and Spanish as second foreign languages continued their participation in the experiment translating the legal texts from these languages into Russian.

The German language learners worked with the legal texts "Justiz und Sprache" of the German University of Administrative Sciences in Speyer (http://www.muenster.de/ texte/thomas/Justiz\%20und\%20Sprache.pdf) and the books on professional German (Höcker, 2008; Hoffmann, 2017; Schmuck, 2010).

The students who studied Spanish as a second foreign language practiced translation of the materials from the sites: http://forodelderecho.blogcindario.com/; http://www.todalaley.com.

Then the students' translations from English, German and Spanish into Russian were compared. The extracts from the sites of Court of Justice of the European Union (CJEU) (https://europa.eu/european-union/about-eu/institutions-bodies/courtjustice_en) and the European Court of Human Rights (http://www.echr.coe.int/Pages/home.aspx?p=languagedocs) were used as the basis for examination.

Each sample for translation included 1500 characters and the time to complete the task was 45 minutes.

To learn the subjective opinion of the students, the questionary with an open-ended issue was held. The participants of the survey were supposed to mention what grammar phenomena in English as the first foreign language, and what grammar phenomena in the second foreign language they consider as the most difficult for understanding and consequently for translating. 
The methods of mathematical statistics were used to generalize the findings of the research.

\section{Results and Discussion}

The experimental survey was held for three years namely 2015, 2016 and 2017. The data of the survey were generalized, and the average findings were achieved. The issues that cause more difficulties refer to both morphology (the changes in the word form) and syntax (the rules related to the changes in the structure of a sentence and word order).

The findings of the experiment illustrate that by the experts/ teachers/ instructors' opinions, the syntax as a part of grammar is the most challenging aspect for the Russian students' comprehension in all foreign languages under examination.

The results of the experts' evaluation showed that the students studying law at the RUDN University have a weak awareness of the following grammar phenomena (see Table 1).

Table 1: The Experts' Opinion on the Grammar Difficulties

\begin{tabular}{|c|c|c|}
\hline Language & Grammar phenomena & $\begin{array}{c}\text { Number of the } \\
\text { learners - } \%\end{array}$ \\
\hline English & $\begin{array}{l}\text { Degrees of Comparison } \\
\text { Different parts of speech with the same form, } \\
\text { e.g., place (noun) - place (verb); after } \\
\text { (preposition) - after (conjunction); } \\
\text { Various clauses } \\
\text { The difference in the plural forms of the } \\
\text { nouns (evidence mostly in the singular in } \\
\text { English and mostly in the plural in Russian) } \\
\text { Complex syntactic structure of a sentence; } \\
\text { Tense forms. Sequence of Tenses } \\
\text { Conditional Mood } \\
\text { Non-finite forms of the verbs (infinitive, } \\
\text { gerund, participle) and complexes; } \\
\text { Modal verbs with the passive infinitive }\end{array}$ & $\begin{array}{l}40 \% \\
60 \% \\
80 \% \\
80 \%\end{array}$ \\
\hline German & $\begin{array}{l}\text { The transformation of the syntactic structure } \\
\text { of a sentence } \\
\text { The parts of speech discrepancy in the source } \\
\text { (German) and target (Russian) languages } \\
\text { The discrepancy of tense forms of the verbs } \\
\text { The discrepancy in the degrees of } \\
\text { comparison, e.g. "von größter Bedeutung" is } \\
\text { the superlative degree refers to "great }\end{array}$ & $\begin{array}{l}55 \% \\
60 \% \\
63 \%\end{array}$ \\
\hline
\end{tabular}

XLinguae, Volume 11 Issue 1, January 2018, ISSN 1337-8384, eISSN 2453-711X 


\begin{tabular}{|c|l|c|}
\hline & $\begin{array}{l}\text { importance." } \\
\text { The difference in the plural forms of the } \\
\text { nouns in the source and target languages } \\
\text { The transformation of the verbal } \\
\text { constructions into the nominative ones } \\
\text { The discrepancy of voice forms of the verbs }\end{array}$ & $72 \%$ \\
\hline Spanish & $\begin{array}{l}\text { Compound nominal and verbal predicates } \\
\text { Personal pronouns as direct and indirect } \\
\text { objects } \\
\text { Gerund forms of the reflexive verbs } \\
\text { Individual conjugation and deviant verbs used } \\
\text { in different tenses } \\
\text { Tense forms. Sequence of Tenses } \\
\text { Subjunctive Mood }\end{array}$ & $25 \%$ \\
\hline
\end{tabular}

In the experts' opinion, many difficulties are caused by nine grammar topics in the English language, by seven grammar topics in the German language and by six grammar topics in the Spanish language (Table 1).

The experiment held among the students of the Law Institute illustrated that the interlinguistic challenges concern morphology and syntax, but the share of syntax issues that were more difficult for the Russian learners was greater. Comparing the teachers' and learners' opinions, it is interesting to note that their views do not correlate

The students' opinion was achieved as a result of the analysis of the translations made by the learners studying law in a bachelor and master courses. The results of the students' survey are shown in Table 2.

Table 2: The Students 'Opinion on the Grammar Difficulties

\begin{tabular}{|l|l|c|}
\hline Language & \multicolumn{1}{|c|}{ Grammar phenomena } & $\begin{array}{c}\text { Number of the } \\
\text { learners - \% }\end{array}$ \\
\hline English & $\begin{array}{l}\text { Different parts of speech with the same form, } \\
\text { e.g., place (noun) - place (verb); after } \\
\text { (preposition) - after (conjunction); } \\
\text { Complex syntactic structure of a sentence; } \\
\text { definite word order } \\
\text { Tense forms. Sequence of Tenses } \\
\text { The use of articles }\end{array}$ & $30 \%$ \\
\hline German & $\begin{array}{l}\text { A bunch of verbs in one sentence } \\
\text { The difference in the plural forms of the }\end{array}$ & $80 \%$ \\
\hline
\end{tabular}




\begin{tabular}{|c|c|c|}
\hline & $\begin{array}{l}\text { nouns: e.g., Steuererhohungen is the plural } \\
\text { the corresponding noun "increase" in Russian } \\
\text { is in the singular. } \\
\text { The Passive Voice of the verbs } \\
\text { The transformation of the nominative } \\
\text { construction into the noun+verb construction } \\
\text { or verbal constructions into the nominative } \\
\text { ones } \\
\text { The necessity to expand sentences in a target } \\
\text { language (Russian) adding conjunctions and } \\
\text { prepositions }\end{array}$ & $\begin{array}{l}43 \% \\
47 \%\end{array}$ \\
\hline Spanish & $\begin{array}{l}\text { Indirect objects and reflexive verbs } \\
\text { Passive voice of the verbs } \\
\text { Expanded sentences with a large number of } \\
\text { subordinate clauses or detached parts of a } \\
\text { sentence } \\
\text { Individual conjugation and deviant verbs used } \\
\text { in different tenses } \\
\text { Tense forms } \\
\text { Subjunctive Mood }\end{array}$ & $\begin{array}{l}55 \% \\
60 \% \\
80 \%\end{array}$ \\
\hline
\end{tabular}

Having compared the results of the experiment, it seems possible to say that the learners determine less complicated issues than the experts/teachers/instructors.

The students mostly do not agree with their teachers and consider that fewer grammar aspects are difficult for studying and understanding. The English language learners pointed at four difficult issues that are twice as less than the teachers' data. The German language learners are more optimistic and self-confident in their abilities to perceive the legal setting information in a foreign language; they focused on four issues as the most difficult. The Spanish language learners agree with their teachers as far as the number of difficult grammar issues are concerned (Table 2).

The qualitative results differ though not greatly. It can be explained by the following factors: the teachers can anticipate the grammar mistakes made by the learners; they assess the students' translations more strictly. Whereas the English language students, first, have had a longer period of English learning, and, then, they are more aware of their specialty and the information related to the setting they study. Therefore, as the output of the content and language integrated learning the English language learners can transfer the subject knowledge into the field of the foreign language studying. Here we can observe a positive interlanguage interference.

The experience of learning the first foreign language (English) makes a positive effect on the students' abilities to learn the second foreign language. At the same time, the grammar skills in English can cause some negative interference in studying the grammar of other foreign languages.

It is interesting to examine what grammar aspects are more and less difficult for the teachers' or/and learners' points of view. 
According to Table 1, some aspects in the English grammar being mentioned by the teachers as the most difficult ("Conditional Mood", "Non-finite forms of the verbs (infinitive, gerund, participle) and complexes", "Modal verbs with the passive infinitive") were not mentioned by the students at all. In fact, these issues cannot be comprehended by the Russian-speaking learners with ease. The first reason is the absence of such part of speech as a gerund. Infinitive and participle in Russian do not form any complexes. All verbal forms, namely tense, voice, mood are formed synthetically, i.e., using verbal endings and suffixes. Whereas the English language is rather analytic, the verbs and non-finite forms of the verbs (infinitive, gerund, participle) are conjugated mostly with the help of the various auxiliary verbs in different forms (Carter, McCarthy, 2016; Carter, Nunan, 2001).

On the other hand, unlike the teachers, the students think that the most difficult issue for comprehension ( $85 \%$ ) is "the use of articles" (Table 2). It can also be explained by the lack of such part of speech in the Russian language and what is more by a great number of rules how to use them with many exceptions.

Both categories of respondents agree that some grammar issues in English can cause difficulties. Sometimes the level of the correlation is identical. Thus $30 \%$ of both teachers and students think that to translate some words correctly one should first study the syntactic structure of the utterance and the determinants of the particular part of speech. Therefore, in legal setting the word, "sentence" means a noun or a verb. What is more the students use the word in the meaning of general English? In other cases, the experiment participants agreed that some grammar issues might be difficult for comprehension, but they differ in quantity. The discrepancy of the values equals $20 \%$ as far as the complex syntactic structure of a sentence, and the use of tense forms and sequence of tenses are concerned.

Three grammar aspects were not mentioned as difficult by the student respondents. Usually, the degrees of comparison of adjective and adverb is thoroughly studied at regular secondary and high school. This topic seems to be familiar and well studied by the learners. On the contrary, the teachers assume it as a difficult issue for perception and use taking into consideration such chunks as "as/so/ not so ... adjective / adverb... as"; "the...the"... with comparatives; the use of "than."

In our opinion, the absence of the issue on the various clauses in the students' responses can be explained by the following. The learners either assume this topic as a part of the syntactic analysis of a sentence or are not familiar with this aspect at all. The plural and the singular forms of the nouns are perceived and comprehended spontaneously based on the awareness of the Russian language.

The observation of the respondents' views and the corresponding mathematical values of their responses showed that the tendencies in the perception of the grammar aspects in German and Spanish as the second foreign languages are similar to the ones in English, namely:

- The current study proved that all issues related to the syntactic structure of a sentence, all kinds of transformations, conjugation of verbs intense, voice, and mood are among the most difficult grammar aspects mentioned by the experiment participants both teachers and students no matter what foreign language is examined.

- The opinion of the respondents can differ depending on the party they belong to, either a teacher/ an expert or a student. E.g., $25 \%$ of the students are sure that a great number of verbs in a German sentence are difficult for understanding, whereas the teachers of German do not consider it as an obstacle. In Spanish, such difference can be viewed regarding the indirect objects, and reflexive verbs that are considered as quite challenging for students and the teachers do not mention this aspect as difficult.

- The mathematical values of the teachers' responses alter from 20-25\% as the lowest level of complexity to $80-82 \%$ as the highest level of 
complexity. The students' responses indicate $25-30 \%$ as the lowest level of complexity, and the highest level of complexity is mentioned by the same quality of the respondents $-80-85 \%$ of the respondents studying English and then Spanish. It is interesting to note that only $65 \%$ of the respondents studying German agreed on the most difficult issue in grammar (the expansion of the sentence translating from German into Russian).

\section{Conclusion}

Taking into consideration the current state of teaching and training communication skills of a foreign language for specific purposes at non-language higher education institutions, the present research sets a hypothesis whether the awareness of grammar phenomena that the students concentrate on is sufficient enough to deal with in the professional written and oral communication.

The main aim of the study was to analyze the grammar issues that cause difficulties for learners from their point of view and the point of view of the teachers/instructors. The research was concentrated on the samples of the written communication, i.e., written translations of the utterances from one of the European foreign languages (English, German and Spanish). Here English was the students' first foreign language, and German and Spanish were the second foreign languages. The samples for the experiment were the extracts from the resources related to the students' profession-tobe.

The examination of the students' translations revealed the fact there are many grammar phenomena that cause misunderstanding or wrong comprehension of the original idea. These grammar obstacles are general for the languages under study; on the other hand, some of them are typical only of one language mentioned above.

The findings of the experiment suggest the recommendations to be implemented in the foreign language teaching practice.

Training grammar skills in non-language higher education institutions should regularly be realized in the whole course of studies at the bachelor and master degree levels of education.

The further development of grammar skills should take into account the interlanguage interference, i.e., the influence of the students' native language (not only Russian but the local languages of various regions of Russia) and the other foreign language that the student studied at different levels of education.

Grammar skills of the foreign language for specific purposes should be trained on the materials selected and worked out for a particular setting. Consequently, a particular students' book should be designed for practical use.

Those mentioned above will allow the learners of non-language universities to overcome the obstacles in the understanding the up-to-date information in the setting of their professional perspective activity.

The research was conducted as part of the RUDN University participation in 5-100 project.

\section{Acknowledgements}

The publication was prepared with the support of the RUDN University program 5100 .

\section{Bibliographic references}

AGCAM, R. - COBAN, M. - CISDIK Z.K. 2015. Second Language Acquisition of Syntactic Movement in English by Turkish Adult Learners. In: Üniversitepark Bülten, vol. 4, n. 1-2, pp. 23-36. ISSN 2147-351X. 
ATABEKOVA, A. 2011. Insights into Multi Lingual Training Methodology for Lawyers-To-Be: Challenges and Solutions. In: EDULEARN 11 Proceedings, Barcelona, Spain, pp. 4979-4982. ISBN 978-84-615-0441-1.

AYOUN, D. 2017. Grammatical gender assignment in French: dispelling the native speaker myth. In: Journal of French Language Studies, vol. 27, n. 2, pp. 1-36. ISSN 1474-0079.

BONDARENKO, O. 2014. Does Russian English Exist? In: American Journal of Educational Research, vol. 2, n. 9, pp. 832-839. ISSN 2327-6150.

CARTER, R. - McCARTHY, M. 2016. English Grammar Today. Book with Workbook. Cambridge: Cambridge University Press. ISBN 1316617394.

CARTER, R. - NUNAN, D. 2001. The Cambridge Guide to Teaching English to Speakers of Other Languages. Cambridge, UK: Cambridge University Press. ISBN 9780521805162.

COULTHARD, M. - JOHNSON, A. 2007. An Introduction to Forensic Linguistics Language in Evidence. London - New York: Routledge. ISBN 0-203-96971-5.

ELLIS, R. - LOEWEN, S. - ERLAM R. 2006. Implicit and Explicit Corrective Feedback and the Acquisition of L2 Grammar. In: Studies in Second Language Acquisition, vol. 28, n. 2, pp. 339-368. ISSN 1470-1545.

ESCOBAR-ALVAREZ, M.A. 2017. L2 Acquisition of Spanish Dative Clitics by English and Dutch Learners. In: Studies in Second Language Learning and Teaching, vol. 7, n. 3, pp. 517-534. ISSN 2083-5205.

FAMULARSIH, S. 2014. The Interlanguage Interference on the Difficulties of Building Question Sentences by the Second Year Students of MA as Soorkaty Salatiga. In: Register Journal, vol. 7, n. 1. ISSN 2503-040X. Available online: http://ijims.iainsalatiga.ac.id/index.php/register/article/view/234

GARRARD, J.G. 1962. The Teaching of Foreign Languages in the Soviet Union. In: The Modern Language Journal, vol. 46, n. 2, pp. 71-74. ISSN 0026-7902.

HOCKER, R. 2008. Langenscheidt Anwalt-Deutsch/Deutsch-Anwalt: Wir verstehen uns vor Gericht. München: Langenscheidt Verlag. ISBN 9783468732126.

HOFFMANN, M. 2017. Deutsch fürs Jurastudium. In: 10 Lektionen zum Erfolg. Stuttgart, Germany: UTB GmbH. ISBN 3825247287.

HOPKINSON, C. 2007. Factors in Linguistic Interference: A Case of Study in Translation. In: SKASE Journal of Translation and Interpretation, vol. 2, n. 1. ISSN 1336-7811.Available online: http://www.skase.sk/Volumes/JTI02/pdf_doc/2.pdf

HOUSEN, A. - SIMOENS, H. 2016. Introduction: Cognitive perspectives on difficulty and complexity in L2 acquisition. In: Studies in Second Language Acquisition, vol. 38, n. 02, pp. 163-175. ISSN 1470-1545.

HUDDLESTON, R. - PULLUM, J.K. 2002. The Cambridge Grammar of the English Language. Cambridge, UK: Cambridge University Press. ISBN: 9780521431460.

KOSARKOVA, M. 2013. Die Textlinguistisch-stilistische Analyse von juristischen Fachtexten aus dem Bereich von Handelsrecht. Thesis on Bachelor's Degree. Olomouc: Olomouc Univerzita Palackého v Olomouci. Available online: https://theses.cz/id/uvzhe9/00177422-459912212.pdf

OLLER, J. W. Jr. 1979. The psychology of language and contrastive linguistics: The research and the debate. In: Foreign Language Annals, vol. 12, pp. 299-309. ISSN 1944-9720.

SCHMUCK, M. 2010. Deutsch für Juristen Vom Schwulst zur klaren Formulierung. Frankfurt Mein: Verlag Otto Schmidt. ISBN 3504644109.

VILLEGAS, B. - MORGAN-SHORT, K. 2017. The Role of Training Condition and Individual Differences on the Development of a Complex Form: An L2 Study of the Spanish Subjunctive. In: Second Language Research Forum, The Ohio State University. Available online: https://www.researchgate.net/publication/320622668_The_role_of_training_condition 
_and_individual_differences_on_the_development_of_a_complex_form_An_L2_stud y_of_the_Spanish_subjunctive

YALÇIN, S. - SPADA, N. 2016. Language Aptitude and Grammatical Difficulty. In: Studies in Second Language Acquisition, vol. 38, n. 2, pp. 239-263. ISSN 1470-1545. YULE, G. 2016. The Study of Language. 6th Edition. Cambridge, UK: Cambridge University Press. ISBN: 9781316606759.

Words: 4285

Characters: 28821 (16,01 standard page)

Assoc. Prof. Nataliya M. Belenkova, PhD.

Law Institute

Foreign Languages Department

Peoples' Friendship University of Russia - RUDN University

6 Miklukho Maklay st.

117198 Moscow

Russia

belenkovanm@gmail.com; belenkova_nm@pfur.ru

Senior Lecturer, Irina I. Kruse, $\mathrm{PhD}$.

Law Institute

Foreign Languages Department

Peoples' Friendship University of Russia - RUDN University

6 Miklukho Maklay st.

117198 Moscow

Russia

kruseirina@gmail.com; kruse_ii@pfur.ru

Senior Lecturer, Victoria V. Davtyan

Law Institute

Foreign Languages Department

Peoples' Friendship University of Russia - RUDN University

6 Miklukho Maklay st.

117198 Moscow

Russia

davtyanv@mail.ru; davtyan_vv@ pfur.ru

Assoc. Prof. Doris Wydra, MMAG, PhD

Department of Political Science

University of Salzburg

2, Mönchsberg, 5020, Salzburg

Austria

doris.wydra@sbg.ac.at

XLinguae, Volume 11 Issue 1, January 2018, ISSN 1337-8384, eISSN 2453-711X 